\title{
EVALUASI AKTIVITAS ANTIOKSIDAN EKSTRAK ETANOL SPONS Aplysina sp. DARI PERAIRAN SELAT LEMBEH KOTA BITUNG
}

\author{
Aprilia H. Manumpil $^{1)}$, Defny S. Wewengkang ${ }^{1)}$, Adithya Yudistira ${ }^{1)}$ \\ ${ }^{1)}$ Program Studi Farmasi FMIPA UNSRAT Manado, 95115
}

\begin{abstract}
Aplysina sp. Sponge is one of the marine biota making up coral reefs that contain active compounds whose percentage of activity is greater than the compounds produced by land plants. This study aims to determine the activity of antioxidant compounds from the ethanol extract of Aplysina sp. from Lembeh Strait Waters, Bitung City. Sponge Aplysina sp., was extracted by maceration with ethanol as a solvent. As a parameter, testing of antioxidant activity was carried out using the DPPH (1,1-diphenyl-2picrylhydrazyl) method, which was measured using UV-Vis Spectrophotometry at a wavelength of 517 $n m$. The result showed the ethanol extract of Aplysina sp., sponge proven to have antioxidant activity in each concentration test. The highest concentration has an antidote to free radical activity by reaching a percentage of $46,13 \%$.
\end{abstract}

Keywords: Aplysina sp. Sponge, Antioxidant, Extraction, DPPH

\begin{abstract}
ABSTRAK
Spons Aplysina sp. merupakan salah satu biota laut penyusun terumbu karang yang mengandung senyawa aktif yang presentase keaktifannya lebih besar dibandingkan dengan senyawa-senyawa yang dihasilkan oleh tumbuhan darat. Penelitian ini bertujuan untuk mengetahui aktivitas senyawa antioksidan dari ekstrak etanol Spons Aplysina sp. dari Perairan Selat Lembeh, Kota Bitung. Spons Aplysina sp. diekstraksi menggunakan metode maserasi dengan etanol sebagai pelarut. Sebagai parameter, pengujian aktivitas antioksidan dilakukan dengan metode DPPH (1,1-difenil-2-pikrilhidrazil) yang diukur menggunakan Spektrofotometri UV-Vis pada panjang gelombang $517 \mathrm{~nm}$. Hasil penelitian menunjukkan ekstrak etanol spons Aplysina sp. terbukti memiliki aktivitas antioksidan disetiap konsentrasi pengujian.Konsentrasi tertinggi memiliki aktivitas penangkal radikal bebas dengan mencapai presentase $46,13 \%$.
\end{abstract}

Kata Kunci : Spons Aplysina sp, Antioksidan, Ekstraksi, DPPH 


\section{PENDAHULUAN}

Radikal bebas merupakan salah satu bentuk senyawa reaktif, yang secara umum diketahui sebagai senyawa yang memiliki elektron yang tidak berpasangan di kulit terluarnya. Radikal bebas sebagai molekul atom dengan elektron bebas dalam jumlah normal dapat berfungsi dalam membunuh virus dan bakteri, namun dalam jumlah yang sangat besar zat ini dapat merusak jaringan normal, menganggu produksi DNA, merusak dinding sel khususnya lapisan lipid, serta mempengaruhi pembuluh darah. Radikal bebas dapat ditangkal atau diredam dengan pemberian antioksidan (Halliwel, 2007).

Antioksidan berupa senyawa kimia yang dapat menyumbangkan satu atau lebih elektron kepada radikal bebas, sehingga reaksi radikal bebas tersebut dapat terhambat. Penggunaan senyawa antioksidan berkembang dengan pesat, baik untuk makanan maupun pengobatan. Penggunaannya sebagai obat semakin meningkat dengan bertambahnya pengetahuan tentang aktivitas radikal bebas terhadap beberapa penyakit degeneratif seperti penyakit jantung, diabetes, kanker, inflamasi jaringan, kelainan imunitas dan penuaan dini (Jacob dan Burri, 1996).

Spons adalah organisme laut yang memiliki potensi cukup besar dalam menghasilkan senyawa aktif. Untuk menjaga kelangsungan hidup dan pertahanan dirinya, spons menghasilkan metabolit primer dan metabolit sekunder. Spons mengandung senyawa aktif yang presentase keaktifannya lebih besar dibandingkan dengan senyawasenyawa yang dihasilkan oleh tumbuhan darat (Muniarsih dan Rachmaniar, 1999).
Spons diketahui menghasilkan senyawa bioaktif yang bermanfaat sebagai antibiotik, anti jamur, anti kanker, anti inflamasi dan antioksidan yang selama ini masih terus dieksplorasi. Salah satu metode yang sering dipakai dalam menguji aktivitas antioksidan yaitu metode DPPH (1,1-difenil-2pikrilhidrazil). Dari penelitian-penelitian tentang spons yang telah dilakukan sebelumnya mendorong peneliti untuk melakukan penelitian untuk membuktikan bahwa spons Aplysina sp. memiliki kandungan metabolit sekunder yang dapat berpotensi sebagai antioksidan.

\section{METODOLOGI PENELITIAN}

Alat

Alat-alat yang digunakan pada penelitian ini yaitu scuba diving, kamera, gunting, pisau, wadah botol air kemasan 600 $\mathrm{mL}$, cawan porselin, ziplok, sarung tangan, telenan, gelas ukur, erlenmeyer, kaca arloji, labu ukur (100 $\mathrm{mL}$ dan $50 \mathrm{~mL})$, tabung reaksi, rak tabung reaksi, baker glass, vortex (Benchmark), corong, pipet tetes, mikro pipet, timbangan digital (AE ADAM), spatula, oven dan spektrofotometer UV-Vis (UV-1800).

\section{Bahan}

Bahan-bahan yang digunakan pada penelitian ini yaitu Spons Aplysina sp., etanol 96\%, kertas saring, tissue, alumunium foil, kertas label, serbuk vitamin c p.a dan serbuk DPPH (1,1-difenil-2-pikrilhidrazil). 


\section{Prosedur Kerja}

\section{Pengambilan Sampel}

Sampel spons Aplysina sp. diperoleh dari perairan selat Lembeh, Kota Bitung. Sampel diambil dengan menggunakan alat bantu (masker, shorkel, fins, tabung oksigen, ziplok dan pisau), kemudian di masukkan dalam ziplok dan diberikan lebel. Kantong sampel dimasukkan kedalam kotak dingin (cool box) yang berisi es batu dan tidak terkena matahari secara lansung. Di Laboratorium Farmakognosi Fitokimia, sampel yang didapat lansung dibersihkan dari pengotor, lalu dipotong kecil-kecil. Sampel yang telah dipotong dimasukkan ke dalam botol dengan menggunakan pelarut etanol 96\% dan sampel tersebut lansung diekstraksi menggunakan metode maserasi.

\section{Ekstraksi Metode Maserasi}

Sampel yang diperoleh sebanyak 430 $\mathrm{g}$ direndam dengan menggunakan larutan etanol 96\%. Metode ekstraksi dilakukan dengan cara merendam sampel dengan larutan penyari selama 3 kali 24 jam pada temperatur kamar yang dilindungi dari cahaya dan sesekali dikocok. Hasil ekstraksi kemudian disaring menggunakan kertas saring $16 \mathrm{x} 16 \mathrm{~cm}$, kemudian diambil filtratnya dan residu di buang.Setelah proses ekstraksi menghasilkan 3 filtrat yang kemudian dicampur menjadi satu. Filtrat tersebut dipekatkan dengan menggunakan oven pada suhu $40^{\circ} \mathrm{C}$ sampai etanol menguap.

\section{Pembuatan Larutan Stok $100 \mathrm{~mL}$}

Sebanyak 100 mg ekstrak etanol spons Aplysina sp. dilarutkandidalam etanol 96\% ad.100 mL (konsentrasi 1000 ppm).
Dengan masing-masing konsentrasi 100 $\mathrm{mg} / \mathrm{L}, 75 \mathrm{mg} / \mathrm{L}, 50 \mathrm{mg} / \mathrm{L}$, dan $25 \mathrm{mg} / \mathrm{L}$ dihitung dengan menggunakan rumus pengenceran, yaitu :

$$
\mathbf{M}_{1} \cdot \mathbf{V}_{1}=\mathbf{M}_{2} \cdot \mathbf{V}_{2}
$$

Pada keempat konsentrasi, masingmasing hasil yang didapatkan dari hasil $\mathrm{V}_{1}$ dipipet dan ditambahkan etanol 96\% hingga mencapai tanda batas (10 $\mathrm{mL})$, kemudian dipindahkan ke dalam tabung reaksi dan ditutup dengan menggunakan aluminium foil untuk digunakan pada perlakuan selanjutnya.

\section{Pembuatan Larutan DPPH}

Penentuan aktivitas penangkal radikal bebas DPPH menurut Burda dan Olezek (2001). Sebanyak $4 \mathrm{mg}$ serbuk DPPH ditimbangdan dilarutkan dalam etanol 96\% sebanyak $100 \mathrm{~mL}$. Selanjutnya larutan stok DPPH dilakukan pengujian kontrol, di uji pada spektrofotometer UV-Vis dengan panjang gelombang antara 400-800 $\mathrm{nm}$.

\section{Pengujian Kontrol Vitamin $\mathbf{C}$}

Setelah pengujian sampel dan pengujian kontrol, dilanjutkan pada pengujian vitamin $\mathrm{C}$ p.a sebagai kontrol pembanding. Kaca arloji ditimbang, vitamin $\mathrm{C}$ ditimbang sebanyak $10 \mathrm{mg}$. Kemudian, vitamin C p.a dilarutkan dalam etanol $96 \%$ sebanyak $10 \mathrm{~mL}$, buat larutan stok dengan konsentrasi yang sama sebelumnya yaitu konsentrasi $100 \mathrm{mg} / \mathrm{L}, 75 \mathrm{mg} / \mathrm{L}, 50 \mathrm{mg} / \mathrm{L}$ dan $25 \mathrm{mg} / \mathrm{L}$ dengan ditambahkan masingmasing larutan dengan etanol $96 \%$ mencapai 
tanda batas $(10 \mathrm{~mL})$, dengan pengulangan sebanyak 3 kali pada masing-masing konsentrasi. Pada masing-masing konsentrasi di pipet $2 \mathrm{~mL}$ dan ditambahkan larutan DPPH $2 \mathrm{~mL}$, di vorteks selama 2 menit dan diinkubasi selama 30 menit pada suhu $37^{\circ} \mathrm{C}$. Sampel vitamin C p.a diuji pada spektrofotometer UV-Vis dengan panjang gelombang $517 \mathrm{~nm}$.

\section{Pengujian Aktivitas Antioksidan Metode DPPH}

Penentuan aktivitas penangkal radikal bebas DPPH menurut Burda dan Olezek (2001). Diambil sebanyak $2 \mathrm{~mL}$ ekstrak etanol spons Aplysina sp. dengan konsentrasi $100 \mathrm{mg} / \mathrm{L}, 75 \mathrm{mg} / \mathrm{L}, 50 \mathrm{mg} / \mathrm{L}$ dan $25 \mathrm{mg} / \mathrm{L}$ ditambahkan masing-masing 2 $\mathrm{mL}$ larutan DPPH dalam etanol dan divorteks selama 10 detik. Berubahnya warna ungu menjadi warna kuning menunjukkan efisiensi penangkal radikal bebas. Diukur absorbansi pada spektrofotometer UV-Vis dengan panjang gelombang $517 \mathrm{~nm}$ setelah diinkubasi selama 30 menit. Kemudian diamati perbandingannya dengan vitamin $\mathrm{C}$ p.a sebagai standar. Setelah absorbansi didapat, aktivitas penangkapan radikal bebas (persen inhibisi) dihitung sebagai persentase berkurangnya warna DPPH dengan menggunakan rumus berikut:

$$
\% \text { inhibisi }=1 \frac{\text { Absorbansi sampel }}{\text { Absorbansi kontrol }} \times 100 \%
$$

\section{HASIL DAN PEMBAHASAN}

Dari hasil pengukuran pada penelitian ini diperoleh absorbansi yang kemudian digunakan untuk perhitungan nilai persen inhibisi atau persen perendaman senyawa antioksidan terhadap DPPH. Data persen inhibisi ekstrak etanol spons Aplysina sp. dan Vitamin C p.a sebagai pembanding disajikan pada tabel 1 berikut ini :

Tabel 1. Hasil pengujian perbandingan antara Ekstrak Etanol Spons Aplysina sp. dan Vitamin C p.a

\begin{tabular}{|c|c|c|c|c|c|}
\hline \multirow{2}{*}{\multicolumn{2}{|c|}{ Pengulangan }} & \multicolumn{4}{|c|}{ Konsentrasi } \\
\hline & & \multirow{2}{*}{$\begin{array}{c}\mathbf{2 5} \\
\mathbf{m g} / \mathbf{L} \\
43,80 \%\end{array}$} & \multirow{2}{*}{$\begin{array}{c}\mathbf{5 0} \\
\mathbf{m g} / \mathbf{L} \\
44,20 \%\end{array}$} & \multirow{2}{*}{$\begin{array}{c}\mathbf{7 5} \\
\mathbf{m g} / \mathbf{L} \\
44,80 \%\end{array}$} & \multirow{2}{*}{$\begin{array}{c}\begin{array}{c}\mathbf{1 0 0} \\
\mathbf{m g} / \mathrm{L}\end{array} \\
46,50 \%\end{array}$} \\
\hline I & Ekstrak & & & & \\
\hline & Vit.C & $93,90 \%$ & $92,90 \%$ & $93,80 \%$ & $93,90 \%$ \\
\hline & Ekstı & $43,70 \%$ & $44,70 \%$ & $45,10 \%$ & $46,10 \%$ \\
\hline & Vit. C & $94,00 \%$ & $93,60 \%$ & $93,30 \%$ & $93,90 \%$ \\
\hline \multirow{2}{*}{ III } & Ekstrak & $43,50 \%$ & $43,80 \%$ & $46,20 \%$ & $45,80 \%$ \\
\hline & Vit. C & $93,90 \%$ & $93,60 \%$ & $93,80 \%$ & $93,60 \%$ \\
\hline \multirow{2}{*}{$\begin{array}{c}\text { Rata- } \\
\text { rata }\end{array}$} & Ekstrak & $43,66 \%$ & $44,23 \%$ & $45,36 \%$ & $46,13 \%$ \\
\hline & Vit. C & $93,93 \%$ & $93,36 \%$ & $93,63 \%$ & $93,80 \%$ \\
\hline & Uji & aktivita & \multicolumn{2}{|c|}{ antioksidan } & suatu \\
\hline \multirow{7}{*}{\multicolumn{6}{|c|}{$\begin{array}{l}\text { tanaman maupun biota laut sangat penting } \\
\text { dilakukan untuk mengetahui apakah dari } \\
\text { tanaman atau biota laut tersebut terbukti } \\
\text { memiliki aktivitas pengikatan terhadap } \\
\text { radikal bebas. Pada penelitian ini, biota laut } \\
\text { yang digunakan yaitu spons Aplysina sp. } \\
\text { Pada penelitian Marzuki, (2016) diketahui } \\
\text { spons Aplysina sp. mengandung simbion }\end{array}$}} \\
\hline & & & & & \\
\hline & & & & & \\
\hline & & & & & \\
\hline & & & & & \\
\hline & & & & & \\
\hline & & & & & \\
\hline \multicolumn{6}{|c|}{$\begin{array}{l}\text { spons Aplysina sp. mengandung simbion } \\
\text { yaitu bakteri Arthrobacter sp., Bacillus sp., } \\
\text { Micrococcus sp., Pseudomonas sp., Vibrio }\end{array}$} \\
\hline
\end{tabular}


sp. dan Aeromonas sp. memiliki aktivitas sebagai antimikroba sehingga kemungkinan untuk spons Aplysina sp. juga dapat mengandung senyawa metabolit sekunder sebagai aktivitas antioksidan yang diproduksi ketika mempertahankan diri dari lingkungan maupun dari serangan organisme lain.

\section{Sebagai parameter pengujian} antioksidan dilakukan dengan menggunakan metode DPPH (1,1-difenil-2-pikrilhidrazil). Pemilihan metode ini karena merupakan metode yang sederhana, mudah, cepat dan peka serta hanya memerlukan sedikit sampel untuk evaluasi aktivitas antioksidan. DPPH (1,1-difenil-2-pikrilhidrazil) merupakan radikal bebas sintetik berwarna ungu yang banyak digunakan dalam uji aktivitas antioksidan. Larutan radikal bebas DPPH memiliki atom nitrogen yang tidak berpasangan. Reaksi DPPH dengan atom hidrogen yang terdapat dalam antioksidan dapat membuat larutan DPPH menjadi berkurang reaktivitasnya, yang ditunjukkan dengan memudarnya warna ungu menjadi kuning. Perubahan warna ini mengakibatkan perubahan absorbansi pada panjang gelombang maksimum DPPH menggunakan spektrofotometri UV-Vis yang menjadi patokan (Molyneux, 2004). Penetuan panjang gelombang serapan maksimum $(\lambda$ maks) larutan DPPH dilakukan dengan mengukur absorbansi larutan pada panjang gelombang antara 400-800 $\mathrm{nm}$. Hasil yang didapatkan pada penelitian ini adalah 517 nm dan memiliki absorbansi kontrol 0,715.

dalam penelitian ini menggunakan perbandingan $1: 1$ yang artinya $2 \mathrm{~mL}$ larutan DPPH dicampurkan dengan $2 \mathrm{~mL}$ larutan sampel (ekstrak etanol spons Aplysina sp. atau vitamin C) pada tiap konsentrasi yang berbeda-beda. Sempurnanya campuran DPPH dan ekstrak dibantu dengan perlakuan di vortex selama 10 detik. Berkurangnya intensitas warna larutan DPPH tersebut dapat menunjukkan bahwa terjadi reaksi antara atom hidrogen yang dilepas oleh bahan uji dengan molekul radikal DPPH sehingga terbentuk senyawa 1,1-difenil-2pikrilhidrazil yang berwarna kuning (Rumagit, 2015).

Konsentrasi ekstrak etanol spons Aplysina sp. yang digunakan adalah 100 $\mathrm{mg} / \mathrm{L}, 75 \mathrm{mg} / \mathrm{L}, 50 \mathrm{mg} / \mathrm{L}$, dan $25 \mathrm{mg} / \mathrm{L}$. Masing-masing konsentrasi dicampurkan dengan larutan DPPH dengan perbandingan yang ada. Campuran dihomogenkan dan diinkubasi selama 30 menit pada tempat gelap dengan suhu $37^{\circ} \mathrm{C}$. Hal ini dilakukan untuk menghindari kontaminasi dan mengoptimalkan aktivitas DPPH agar terjadi reaksi antara DPPH dengan sampel yang diuji (Hatano et al., 1998). Setelah diinkubasi, kemudian masing-masing ekstrak dilakukan pengukuran absorbansi dengan menggunakan spektrofotometer pada panjang gelombang serapan maksimum $(\lambda$ maks) DPPH $517 \mathrm{~nm}$. Pada tiap konsentrasi dilakukan sebanyak 3 kali pengulangan.

Pembanding yang digunakan sebagai kontrol positif adalah vitamin C p.a dimana sebagai pembanding karena berfungsi sebagai antioksidan sekunder yaitu menangkap radikal bebas, mencegah terjadinya reaksi berantai, aktivitas antioksidannya sangat tinggi dan vitamin $\mathrm{C}$ lebih polar dari vitamin yang lain. Vitamin $\mathrm{C}$ mempunyai gugus hidroksi bebas yang bertindak sebagai penangkap radikal bebas 
(Isnindar et al., 2011).

Berdasarkan hasil yang diperoleh pada Tabel 1 menunjukkan bahwa pengukuran persen inhibisi pada ekstrak etanol spons Aplysina sp. memiliki aktivitas antioksidan dan mengalami peningkatan dari konsentrasi $25 \mathrm{mg} / \mathrm{L}$ sampai dengan 100 mg/L. Pada ekstrak etanol spons Aplysina sp. dengan konsentrasi $100 \mathrm{mg} / \mathrm{L}$ memiliki persen inhibisi rata-rata paling tinggi yaitu sebesar 46,13\%. Penigkatan persen inhibisi pada ekstrak etanol spons Aplysina sp. menandakan bahwa konsentrasi ekstrak yang ditambahkan mempengaruhi kemampuan ekstrak dalam merendam radikal bebas. Hal ini didukung oleh penelitian yang dilakukan oleh Hanani et al., (2005) yang menyatakan bahwa presentasi penghambat atau persen inhibisi terhadap aktivitas radikal bebas akan ikut meningkat seiring dengan meningkatnya konsentrasi. Hasil pengujian perbandingan aktivitas antioksidan ekstrak etanol spons Aplysina sp. dan vitamin C (Tabel 1) juga menukjukkan bahwa aktivitas antioksidan ekstrak etanol spons Aplysina sp. lebih rendah dibandingkan dengan vitamin $\mathrm{C}$.

Dalam penelitian ini, uji DPPH dilakukan dengan mengamati penurunan absorbansi pada panjang gelombang $517 \mathrm{~nm}$ dengan menggunakan spektrofotometer UVVis. Penurunan nilai absorbansi sebagai akibat dari penurunan intensitas warna dari larutan yaitu dari warna ungu menjadi warna kuning. Penurunan intensitas warna itu terjadi karena penambahan radikal hidrogen dari senyawa antioksidan pada elektron yang tak berpasangan pada radikal nitrogen dalam struktur senyawa DPPH (Rorong, 2008).

Rendahnya aktivitas antioksidan ini kemungkinan disebabkan oleh berbagai faktor, diantaranya karena metode ekstraksi yang digunakan kemungkinan tidak cukup menarik komponen kimia yang bersifat antioksidan dalam spons Aplysina sp. Selain itu vitamin $\mathrm{C}$ merupakan senyawa murni sedangkan ekstrak etanol spons Aplysina sp. masih merupakan senyawa campuran dan belum diketahui kandungan senyawanya yang bersifat antioksidan, dimana adanya senyawa yang tidak bersifat antioksidan kemungkinan bisa mempengaruhi aktivitas antioksidan ekstrak etanol spons Aplysina sp. itu sendiri.Menurut penelitian Palekahelu (2018), rendahnya nilai rendemen juga dapat mempengaruhi hasil.

\section{KESIMPULAN}

Berdasarkan dari hasil penelitian yang telah dilakukan maka, dapat disimpulkan bahwa ekstrak etanol spons Aplysina sp. dari Perairan Selat Lembeh, Kota Bitung memiliki aktivitas antioksidan disetiap konsentrasi. Aktivitas antioksidan tertinggi terlihat pada konsentrasi tertinggi yaitu pada konsentrasi $100 \mathrm{mg} / \mathrm{L}$ dengan mencapai presentase $46,13 \%$.

\section{SARAN}

Perlu dilakukan penelitian lebih lanjut untuk mengetahui senyawa aktif yang terkandung dalam ekstrak etanol spons Aplysina sp. dan pengujian aktivitas antioksidan dengan metode lain dan sebaiknya membandingkan hasilnya dengan penelitian ini.

\section{DAFTAR PUSTAKA}

Burda, S., dan Olezek. 2001. Antioxidant and Antiradical. J.Nat. Prod., 63: 1035-1042. 
Halliwel, B. 2007. Dietary Polyphenols: good, bad or indifferent for your healt. Journal Cardiovascular Research 73:341-347.

Hanani E, Mun'im B, Sekarini R. 2005. Identifikasi senyawa antioksidan dalam spons Callispongia sp. dari Kepulauan Seribu. Jurnal Ilmu Kefarmasian 2 (3) : 127-133. Jurnal (Endang Hanani).

Isnindar et al. 2011. Isolasi dan Identifikasi Senyawa Antioksidan Daun Kesemek (Diopyroskaki Thunb) dengan Metode DPPH. Majalah Obat Tradisional. 16 (3) : 157-164.

Jacob, R.A., dan Burri,C.J. 1996. Oxidative Damage and Defense. J.Clin and Nutr. 63, 985S-990S.

Marzuki, I. 2018. Eksplorasi Spons Indonesia : Seputar Kepulauan Spermonde. Nas Media Pustaka, Makassar.

Molyneux, P. 2004. The Use of The Stable Free Radikal DPPH. J.Sci. Technol. 26 (2) : 211-219. Narins, D.M.C. 1996. Vitamin Dalam Krause's FOOD, Nutrition and Diet Therapy. Mahlan, L.K, hal 110-114..

Muniarsih, T dan Rachmaniar, R. 1999. Isolasi Substansi Bioaktif Antimikroba dari Spons Asal Pulau Pari Kepulauan Seribu. Osean dan Limnologi Indonesia. xxx: 151158. Jurnal (Suparno).
Palekahelu, N. 2018. Aktivitas Antioksidan dan Antibakteri dari Ekstrak Etanol dan Metanol Daun Kapehu (Guioa diplopetala). Jurnal Ilmiah Farmasi 3 (2).

Rorong, J. 2008. Uji Aktivitas Antioksidan dari Daun Cengkeh (Eugenia Carryophyllus) dengan Metode DPPH. Journal Chemistry Progress 1(2).

Rumagit, H., M. Runtuwene., dan S. Sudewi. 2015. Uji Fitokimia dan Uji Aktivitas Antioksidan dari Ekstrak Etanol Spons Lamellodysidea herbacea. Jurnal Ilmiah Farmasi 4 (3). 